\title{
Correlation analysis of genetic diversity and population structure of Houttuynia cordata Thunb with regard to environment
}

\author{
J. Zhong' ${ }^{1}$ F.-C. Wu ${ }^{2}$, P. Qiu ${ }^{2}$ and L.-J. Dai ${ }^{1}$ \\ ${ }^{1}$ College of Agriculture, Hunan Agricultural University, Changsha, Hunan, \\ China \\ ${ }^{2}$ Hunan Zhengqing Pharmaceutical Co. Ltd., Huaihua, Hunan, China \\ Corresponding author: L.-J. Dai \\ E-mail: zhhjp@163.com
}

Genet. Mol. Res. 15 (3): gmr.15038780

Received May 16, 2016

Accepted June 3, 2016

Published August 12, 2016

DOI http://dx.doi.org/10.4238/gmr.15038780

Copyright (C) 2016 The Authors. This is an open-access article distributed under the terms of the Creative Commons Attribution ShareAlike (CC BY-SA) 4.0 License.

\begin{abstract}
To study the levels of genetic diversity, and population structure, of Houttuynia cordata Thunb, the genetic background and relationships of populations were analyzed in terms of environmental factors. The genetic diversity and population structure of $H$. cordata were investigated using sequence-related amplified polymorphisms and correlation with environmental factors was analyzed using the SPSS software. Two thousand one hundred sixty-three sites were amplified from 41 pairs of primers, 1825 of which were polymorphic, and the percentage of polymorphic loci was $84.37 \%$; the percentage of polymorphic sites was 72.14 and $67.77 \%$ at the species and population level, respectively. The observed number of alleles was 1.52 and 1.30 at species and population level, respectively. The effective number of alleles was 1.38 and 1.24 at species and population level, respectively. The Nei's diversity was 0.26 and 0.15 at species and population level,
\end{abstract}


respectively. The Shannon's information index was 0.87 and 0.63 at species and population level, respectively. The genetic differentiation coefficient of populations was 0.51 , and 12 populations were divided into three classes based on $\mathrm{D}=0.20$; the genetic diversities of different populations are correlated at different significance levels $(\mathrm{P}<0.05)$ with environmental factors. Genetic differentiation existed among populations and the populations exhibited heteroplasmy.

Key words: Correlation; Genetic diversity; Environmental factors; Houttuynia cordata Thunb; Population structure

\section{INTRODUCTION}

For angiosperms, asexual reproduction is widespread. Many flowering plants could reproduce asexually using rhizomes, stem buds, layers, cuttings, and grafts (Albert et al., 2003), which considerably influences their genetic diversity, population structure, and adaptation potential. The spatial distribution of genetic structures reflects the functions of adaptation in ecological evolution, environmental transition, and natural selection (O'Hanlon et al., 2000). An in-depth understanding of genetic diversity and structure are important to discern the mechanisms underlying the formation, maintenance, recession, and succession of asexual reproduction among plant populations (Waycott, 1995). For plants with both sexual and asexual reproduction, although sexual reproduction could increase their genetic diversity and decrease their genetic differentiation, their propagation depends on dispersal and the ratio of sexual reproduction to asexual reproduction. Thus, estimating genetic diversity and structure is important in understanding the dynamics and evolution of plants populations (Esselman et al., 1999).

The Houttuynia cordata Thunb, of the family Saururaceae, is a perennial herbaceous plant originating in China. It is mainly distributed in the central, southeast, and southwest regions of China, and grows in wet hillside forest understories and along the roadsides, ridges, and ditches 300-2600 meters above the sea level. Houttuynia cordata Thunb has been officially recognized as a developing resource with huge potential by the National Health Ministry of China. However, with increasing demand and irregular collection, wild Houttuynia cordata Thunb is vastly destroyed, its numbers continuously decrease, its habitats have been fragmented, its gene library is quickly diminished, and its genetic diversity is reduced (Zhong et al., 2009). The different germplasm resources of Houttuynia cordata Thunb vary in their morphological features, yield, quality, disease resistance, and chromosome numbers (Wu et al., 2003). Genetic diversity has been detected at the isozyme (Wu et al., 2002a) and DNA (Wu et al., 2002b) levels. However, their genetic background and associated relationships with environmental factors are still ambiguous. Evidence from population genetic studies suggests that species have a lower level of genetic diversity than progenitors (Pleasants and Wendel, 1989). Despite the economical importance and transcontinental distribution, little is about the genetic diversity and the population structure of Houttuynia cordata Thunb.

The sequence-related amplified polymorphism (SRAP) molecular marker is a novel molecular marker technique developed in 2001. This method has several advantages: it is simple, produces medium yield, is highly co-dominant, repeatable, and easy to isolate and sequence, and is targeted to open reading frames (ORFs). The SRAP primer design is crucial,

Genetics and Molecular Research 15 (3): gmr.15038780 
and is based on the amplification of two primers: the length of the upstream primer is $17 \mathrm{bp}$ comprised of a non-specific filling sequence $(10 \mathrm{bp})$, followed by the core sequence CCGG, three selective bases on the 3 ' end, and specific amplification of the exons; the length of the downstream primer is $18 \mathrm{bp}$ and is composed of an $11 \mathrm{bp}$ non-specific filling sequence on the $5^{\prime}$ end, followed by the core sequence AATT, three selective bases on the $3^{\prime}$ end, and specific amplification of the introns and promoters. The polymorphism generation is due to the gap length between introns and promoters and varies between individual and species. This is being widely used in genetic map construction (Lin et al., 2005), QTL analysis (Okazakik et al., 2007), genetic diversity analysis (Budak et al., 2004), heterosis prediction (Budak et al., 2004), species identification, and other fields.

In this study, we analyzed the genetic diversity, population structure, and spatial distribution of Houttuynia cordata Thunb using the SRAP technique to understand its habitation, asexual reproduction, and ecological adaptation, as well as correlating its genetic diversity with environmental factors.

\section{MATERIAL AND METHODS}

\section{Materials}

A random selection of 20-30 different plants from 12 separate $H$. cordata Thunb populations were collected from the Yunnan (YN), Guizhou (GZ), Sichuan (SC), Shanxi (SX), Jiangxi (JX), Hunan (HN), Hubei (HB), Guangxi (GX), Zhejiang (ZJ), Jiangshu (JS), Fujian (FJ), and Guangdong (GD) provinces in China (Table 1). The fresh young leaves of each plant were placed in a sealed bag with silica gel to keep them dry, and preserved for future use.

\section{Table 1. Populations and habitation factors of Houttuynia cordata Thunb.}

\begin{tabular}{l|c|c|c|c|c|c|c|c|c|c|c|c}
\hline Population & $\mathrm{pH}$ & Altitude $(\mathrm{m})$ & Latitude & Longitude & $\begin{array}{c}\text { Organic } \\
(\mathrm{g} / \mathrm{kg})\end{array}$ & $\begin{array}{c}\mathrm{N} \\
(\mathrm{g} / \mathrm{kg})\end{array}$ & $\begin{array}{c}\mathrm{P} \\
(\mathrm{mg} / \mathrm{kg})\end{array}$ & $\begin{array}{c}\mathrm{K} \\
(\mathrm{mg} / \mathrm{kg})\end{array}$ & $\begin{array}{c}\mathrm{Fe} \\
(\mathrm{mg} / \mathrm{kg})\end{array}$ & $\begin{array}{c}\mathrm{Mn} \\
(\mathrm{mg} / \mathrm{kg})\end{array}$ & $\begin{array}{c}\mathrm{Cu} \\
(\mathrm{mg} / \mathrm{kg})\end{array}$ & $\begin{array}{c}\mathrm{Zn} \\
(\mathrm{mg} / \mathrm{kg})\end{array}$ \\
\hline $\mathrm{YN}$ & 5.21 & 1200 & 27.88 & 108.71 & 39.4 & 2.34 & 10.74 & 181.25 & 144.25 & 2.23 & 0.41 & 4.84 \\
\hline $\mathrm{GZ}$ & 4.85 & 270 & 25.55 & 108.30 & 27.3 & 1.81 & 13.66 & 217.81 & 161.15 & 1.55 & 0.46 & 5.31 \\
\hline SC & 4.62 & 901 & 28.55 & 104.26 & 26.8 & 1.83 & 22.64 & 134.65 & 164.65 & 2.15 & 0.59 & 4.90 \\
\hline SX & 4.97 & 653 & 38.09 & 117.04 & 25.1 & 1.75 & 11.28 & 213.25 & 186.65 & 4.72 & 0.50 & 6.95 \\
\hline HN & 5.09 & 896 & 25.43 & 114.71 & 40.8 & 2.52 & 5.64 & 149.95 & 179.35 & 2.85 & 0.68 & 6.95 \\
\hline GB & 4.84 & 568 & 27.22 & 109.32 & 24.6 & 1.64 & 9.83 & 236.72 & 180.25 & 2.25 & 0.58 & 6.25 \\
\hline GX & 5.17 & 706 & 33.16 & 109.37 & 49.2 & 3.35 & 4.67 & 177.28 & 192.25 & 3.26 & 0.32 & 6.75 \\
\hline JX & 5.69 & 112 & 22.24 & 109.17 & 24.1 & 1.46 & 2.56 & 198.85 & 200.16 & 3.82 & 0.43 & 5.22 \\
\hline FJ & 4.95 & 487 & 30.52 & 120.15 & 38.9 & 3.11 & 3.65 & 217.65 & 202.91 & 3.85 & 0.52 & 6.55 \\
\hline GD & 5.83 & 391 & 31.47 & 119.58 & 40.4 & 2.64 & 2.98 & 224.35 & 166.83 & 6.34 & 0.38 & 8.15 \\
\hline
\end{tabular}

\section{Methods}

DNA extraction and polymerase chain reaction (PCR) amplification were performed as previously reported (Zhong et al., 2010). Sequences of forward and reverse primers are shown in Table 2.

The PCR amplification mixture consisted of $60 \mathrm{ng}$ DNA template, $30 \mathrm{ng}$ each primer, $200 \mu \mathrm{M}$ dNTP, 1X PCR buffer, and 1 U TAKARA Taq DNA polymerase for a total volume of $20 \mu \mathrm{L}$. The thermal cycling profile was as follows: $94^{\circ} \mathrm{C}$ for $2 \mathrm{~min}$, followed by 4 cycles of 1 min at $94^{\circ} \mathrm{C}, 1 \mathrm{~min}$ at $35^{\circ} \mathrm{C}$, and $1 \mathrm{~min}$ at $72^{\circ} \mathrm{C}$, then 34 cycles of $1 \mathrm{~min}$ at $94^{\circ} \mathrm{C}, 1 \mathrm{~min}$ at $50^{\circ} \mathrm{C}$ 
and $1 \mathrm{~min}$ at $72^{\circ} \mathrm{C}$, and a final extension step for $7 \mathrm{~min}$ at $72^{\circ} \mathrm{C}$. Amplified fragments were separated on a $6 \%$ denaturing gel and silver stained.

Table 2. SRAP primers used in the experiment.

\begin{tabular}{l|l|l|l}
\hline Forward primer sequence & Forward primer sequence & Reverse primer sequence & Reverse primer sequence \\
\hline F1: TGAGTCCAAACCGGACC & F7: TGAGTCCAAACCGGAAT & R1: GACTGCGI'ACGAATTGAC & R7: GACTGCGTACGAATTCTG \\
\hline F2: TGAGTCCAAACCGGTAA & F8: TGAGTCCAAACCGGAAG & R2: GACTGCGTACGAATTTGA & R8: GACTGCGI'ACGAATTAAT \\
\hline F3: TGAGTCCAAACCGGTCC & F9: TGAGTCCAAACCGGACA & R3: GACTGCGTACGAATTGAT & R9: GACTGCGTACGAATTTGC \\
\hline F4: TGAGTCCAAACCGGATA & F10: TGAGTCCAAACCGGTGC & R4: GACTGCGTACGAATTCAG & R10: GACTGCGTACGAATTAAC \\
\hline F5: TGAGTCCAAACCGGAGC & F11: TGAGTCCAAACCGGAGA & R5: GACTGCGTACGAATTCTC & R11: GACTGCGTACGAATTGCA \\
\hline F6: TGAGTCCAAACCGGACC & F12: TGAGTCCAAACCGGACG & R6: GACTGCGTACGAATTCAA & R12: GACTGCGTACGAATTGTC \\
\hline
\end{tabular}

The genetic parameters of all populations were analyzed with Popgene Version 1.31 to calculate allele number $\left(N_{\mathrm{A}}\right)$, effective number of alleles $\left(N_{\mathrm{E}}\right)$, Nei's genetic diversity index (h), Shannon phenotype index (I), and percentage of polymorphic site (P). The genetic structure was evaluated using the migration number per population generation $\left(N_{\mathrm{m}}\right)$ and the genetic differentiation coefficient $\left(G_{\mathrm{ST}}\right)$. The computational formulas are as follows (Yeh et al., 1997): $\mathrm{h}=1-\mathrm{a}_{\mathrm{i}}^{2}, \mathrm{p}_{\mathrm{i}}$ is the $\mathrm{i}$ allele frequency of population; $\mathrm{I}=1-\sum \mathrm{F}_{\mathrm{i}}, \mathrm{F}_{\mathrm{i}}$ is the length of amplicons; $\mathrm{P}=$ $\mathrm{k} / \mathrm{n} \times 100 \%, \mathrm{k}$ and $\mathrm{n}$ are the number of polymorphic sites and total sites, respectively; $G_{\mathrm{ST}}=\left(\mathrm{H}_{\mathrm{T}}\right.$ - $\mathrm{Hs}) / \mathrm{H}_{\mathrm{T}}, \mathrm{H}_{\mathrm{T}}$ and $\mathrm{H}_{\mathrm{S}}$ is the genetic diversity among and within populations; $N_{\mathrm{m}}=\left(1-G_{\mathrm{ST}}\right) / 2 G_{\mathrm{ST}}$.

Nei' genetic distance (D) $=1-2 \mathrm{~N}_{\mathrm{ab}} /\left(N_{\mathrm{A}}+\mathrm{N}_{\mathrm{b}}\right) ; \mathrm{N}_{\mathrm{ab}}$ was the number of common bands at two populations, $N_{\mathrm{A}}, \mathrm{N}_{\mathrm{b}}$ was the number of peculiar bands for each population, respectively.

Each band was manually scored as 1 (present) or 0 (absent). The NTSYS-pc2.10e software was used to calculate simple matching coefficients, perform cluster analysis, and identify the goodness of fit of the cluster analysis.

The soil factors among populations were determined using the Analytic Service Center of the Hunan Agricultural University. The correlations between environmental factors and genetic diversity indexes were analyzed using SPSS 12.0 software.

\section{RESULTS}

\section{Amplified polymorphism among populations using SRAP primers on $\boldsymbol{H}$. cordata Thunb}

A total of 41 pairs of repeatable and highly polymorphic primers were selected from 144 pairs of sequence-related amplified polymorphism primers, and 2163 sites were amplified from 41 pairs of primers, 1825 of which were polymorphic. The percentage of polymorphic loci was $84.37 \%$ (Table 3 ). The above data showed that populations are genetically diverse.

\section{Genetic diversity of $\boldsymbol{H}$. cordata Thunb populations}

At the species level of $H$. cordata Thunb, the percentage of polymorphic sites was $72.14 \%$, the observed number of alleles $\left(N_{\mathrm{A}}\right)$ was 1.52 , the effective number of alleles $\left(N_{\mathrm{E}}\right)$ was 1.38 , the Nei's diversity (h) was 0.26 , and the Shannon's information index (I) was 0.87 . At population level of $H$. cordata Thunb, the percentage of polymorphic sites was $67.77 \%$, the observed number of alleles $\left(N_{\mathrm{A}}\right)$ was 1.30 , the effective number of alleles $\left(N_{\mathrm{E}}\right)$ was 1.24 , the Nei's diversity (h) was 0.15 , and the Shannon's information index (I) was 0.63 (Table 4$)$.

Genetics and Molecular Research 15 (3): gmr.15038780 
Table 3. Polymorphism level of SRAP analysis on Houttuynia cordata Thunb populations.

\begin{tabular}{|c|c|c|c|c|c|c|c|}
\hline $\begin{array}{l}\text { Primers } \\
\text { code }\end{array}$ & $\begin{array}{l}\text { Total number of } \\
\text { amplified sites }\end{array}$ & $\begin{array}{c}\text { Number of } \\
\text { polymorphic sites }\end{array}$ & $\begin{array}{c}\text { Percentage of } \\
\text { polymorphic (\%) }\end{array}$ & $\begin{array}{l}\text { Primers } \\
\text { code }\end{array}$ & $\begin{array}{l}\text { Total number of } \\
\text { amplified sites }\end{array}$ & $\begin{array}{c}\text { Number of } \\
\text { polymorphic sites }\end{array}$ & $\begin{array}{c}\text { Percentage of } \\
\text { polymorphic (\%) }\end{array}$ \\
\hline F2-R5 & 72 & 47 & 62.7 & F6-R6 & 72 & 72 & 100 \\
\hline F2-R6 & 70 & 44 & 61.1 & F6-R7 & 79 & 54 & 65.8 \\
\hline F2-R7 & 70 & 70 & 100 & F6-R10 & 34 & 34 & 100 \\
\hline F3-R5 & 30 & 30 & 100 & F7-R9 & 26 & 26 & 100 \\
\hline F3-R6 & 84 & 59 & 67.8 & F7-R8 & 73 & 45 & 61.6 \\
\hline F3-R7 & 78 & 52 & 65.0 & F7-R8 & 40 & 40 & 100 \\
\hline F3-R9 & 24 & 24 & 100 & F8-R8 & 26 & 26 & 100 \\
\hline F3-R10 & 69 & 43 & 60.6 & F9-R10 & 77 & 49 & 63.6 \\
\hline$\overline{F 3-R 11}$ & 45 & 45 & 100 & F10-R3 & 50 & 50 & 100 \\
\hline F3-R12 & 70 & 45 & 61.6 & F10-R8 & 48 & 48 & 100 \\
\hline F4-R1 & 27 & 27 & 100 & F10-R10 & 50 & 50 & 100 \\
\hline F4-R3 & 73 & 47 & 62.7 & F10-R11 & 53 & 53 & 100 \\
\hline F4-R9 & 29 & 29 & 100 & F11-R6 & 66 & 40 & 58.8 \\
\hline F4-R10 & 49 & 49 & 100 & F11-R7 & 63 & 37 & 56.9 \\
\hline F4-R11 & 20 & 20 & 100 & F11-R10 & 61 & 61 & 100 \\
\hline F4-R12 & 45 & 45 & 100 & F11-R11 & 71 & 45 & 61.6 \\
\hline F5-R4 & 48 & 48 & 100 & F12-R2 & 44 & 44 & 100 \\
\hline F5-R5 & 41 & 41 & 100 & F12-R3 & 35 & 35 & 100 \\
\hline$\overline{\text { F5-R8 }}$ & 51 & 51 & 100 & F12-R5 & 43 & 43 & 100 \\
\hline F6-R3 & 45 & 45 & 100 & F12-R9 & 50 & 50 & 100 \\
\hline F6-R5 & 62 & 62 & 100 & Total & 2163 & 1825 & 84.37 \\
\hline
\end{tabular}

Table 4. Genetic diversity of Houttuynia cordata Thunb populations.

\begin{tabular}{|c|c|c|c|c|c|}
\hline Population & $\begin{array}{c}\text { Observed number } \\
\text { of alleles }\left(N_{\mathrm{A}}\right)\end{array}$ & $\begin{array}{c}\text { Effective number } \\
\text { of alleles }\left(N_{\mathrm{E}}\right)\end{array}$ & $\begin{array}{c}\text { Nei's gene } \\
\text { diversity }(\mathrm{h})\end{array}$ & $\begin{array}{c}\text { Shannon's } \\
\text { Information index (I) }\end{array}$ & $\begin{array}{c}\text { Percentage of } \\
\text { polymorphic (\%) }\end{array}$ \\
\hline $\mathrm{YN}$ & 1.23 & 1.18 & 0.14 & 0.75 & 61.04 \\
\hline GZ & 1.16 & 1.14 & 0.10 & 0.66 & 55.69 \\
\hline$\overline{\mathrm{SC}}$ & 1.22 & 1.20 & 0.12 & 0.71 & 59.83 \\
\hline SX & 1.36 & 1.32 & 0.10 & 0.61 & 53.57 \\
\hline JX & 1.39 & 1.34 & 0.23 & 0.65 & 85.51 \\
\hline $\mathrm{HN}$ & 1.46 & 1.33 & 0.28 & 0.56 & 74.28 \\
\hline HB & 1.12 & 1.09 & 0.16 & 0.61 & 85.71 \\
\hline GX & 1.60 & 1.53 & 0.14 & 0.55 & 78.18 \\
\hline ZJ & 1.18 & 1.13 & 0.19 & 0.60 & 66.18 \\
\hline$\overline{J X}$ & 1.49 & 1.41 & 0.13 & 0.53 & 71.43 \\
\hline FJ & 1.19 & 1.13 & 0.11 & 0.65 & 78.57 \\
\hline GD & 1.21 & 1.15 & 0.15 & 0.74 & 67.96 \\
\hline Mean & 1.30 & 1.24 & 0.15 & 0.63 & 67.77 \\
\hline Species level & 1.52 & 1.38 & 0.26 & 0.87 & 72.14 \\
\hline
\end{tabular}

\section{The genetic differentiation and gene flow}

The genetic diversity among and within populations was 0.5331 and 0.2612 , respectively. The genetic differentiation coefficient $\left(G_{\mathrm{ST}}\right)$ of $H$. cordata Thunb populations was 0.51 , which the genetic differentiation among population was slightly higher than of within population (Table 5).

Genetic differentiation existed among populations, and the percentage was 51\% $(\mathrm{P}<0.001)$ according to the AMOVA analysis. The gene flow $\left(N_{\mathrm{m}}\right)$ for $H$. cordata Thunb populations was 0.48 , which indicates that the gene flow of 12 populations was blocked. The Nei's diversity index and gene flow analysis were consistent among populations (Table 6). 
Table 5. Nei's analysis of genetic diversity of Houttuynia cordata Thunb populations.

\begin{tabular}{l|c|c|c|c}
\hline & $\begin{array}{c}\text { Total gene } \\
\text { diversity }(\mathrm{Ht})\end{array}$ & $\begin{array}{c}\text { Gene diversity } \\
\text { in population }(\mathrm{Hs})\end{array}$ & $\begin{array}{c}\text { Index of genetic } \\
\text { differentiation }(G \mathrm{ST})\end{array}$ & $\begin{array}{c}\text { Gene flow } \\
(\mathrm{Nm})\end{array}$ \\
\hline Mean & 0.5331 & 0.2612 & 0.51 & 0.48 \\
\hline
\end{tabular}

Table 6. Analysis of molecular variance (AMOVA) analysis of Houttuynia cordata Thunb. populations.

\begin{tabular}{l|c|c|c|c|c|c}
\hline Source of diversity & Sums of square & Degree of freedom & Mean squares & Variance components & Percentage of variance components (\%) & P \\
\hline Diversity among populations & 1856.92 & 11 & 168.81 & 15.784 & 51 & $<0.001$ \\
\hline Diversity within population & 973.21 & 312 & 3.12 & 15.165 & 49 & \\
\hline Total & 2830.13 & 323 & 171.93 & 30.949 & & \\
\hline
\end{tabular}

\section{Genetic identity (I) and genetic distance (D) among $H$. cordata Thunb populations}

The range of genetic identity (I) two populations of the $12 \mathrm{H}$. cordata Thunb. populations was 0.6881-0.9664, and that of genetic distance (D) was 0.0336-0.3119. The genetic identity (I) was largest between the HN and JX populations (0.9664) and was smallest between the ZJ and FJ population (0.6881) (Table 7).

Table 7. Nei's genetic identity (above diagonal) and genetic distance (below diagonal) among Houttuynia cordata Thunb. populations.

\begin{tabular}{l|c|c|c|c|c|c|c|c|c|c|c|c}
\hline & YN & GZ & SC & SX & JX & HN & HB & GX & ZJ & JX & FJ & GD \\
\hline YN & & 0.8248 & 0.8094 & 0.7653 & 0.8537 & 0.8376 & 0.8443 & 0.8366 & 0.7276 & 0.7753 & 0.6972 & 0.8079 \\
\hline GZ & 0.1752 & & 0.8179 & 0.7540 & 0.8938 & 0.8883 & 0.8757 & 0.8158 & 0.7044 & 0.8053 & 0.6986 & 0.8177 \\
\hline SC & 0.1906 & 0.1821 & & 0.8344 & 0.8258 & 0.8247 & 0.8299 & 0.7946 & 0.7463 & 0.7744 & 0.7063 & 0.8144 \\
\hline SX & 0.2347 & 0.2460 & 0.1656 & & 0.7796 & 0.7639 & 0.7743 & 0.7576 & 0.7663 & 0.7092 & 0.6576 & 0.8169 \\
\hline JX & 0.1463 & 0.1062 & 0.1742 & 0.2204 & & 0.9664 & 0.9581 & 0.8522 & 0.7453 & 0.8679 & 0.7643 & 0.8384 \\
\hline HN & 0.1624 & 0.1117 & 0.1753 & 0.2361 & 0.0336 & & 0.9444 & 0.8476 & 0.7279 & 0.8591 & 0.7673 & 0.8146 \\
\hline HB & 0.1557 & 0.1243 & 0.1701 & 0.2257 & 0.0419 & 0.0556 & & 0.8438 & 0.7459 & 0.8473 & 0.7580 & 0.8257 \\
\hline GX & 0.1634 & 0.1842 & 0.2054 & 0.2424 & 0.1478 & 0.1524 & 0.1562 & & 0.7118 & 0.7547 & 0.7276 & 0.8861 \\
\hline ZJ & 0.2724 & 0.2956 & 0.2537 & 0.2337 & 0.2547 & 0.2721 & 0.2541 & 0.2882 & & 0.7737 & 0.6881 & 0.7672 \\
\hline JX & 0.2247 & 0.1947 & 0.2256 & 0.2908 & 0.1321 & 0.1409 & 0.1527 & 0.2453 & 0.2263 & & 0.7637 & 0.7673 \\
\hline FJ & 0.3028 & 0.3014 & 0.2937 & 0.3424 & 0.2357 & 0.2327 & 0.2420 & 0.2724 & 0.3119 & 0.2363 & & 0.7333 \\
\hline GD & 0.1921 & 0.1823 & 0.1856 & 0.1831 & 0.1616 & 0.1854 & 0.1743 & 0.1139 & 0.2328 & 0.2327 & 0.2667 & \\
\hline
\end{tabular}

According to the Nei's genetic distance, a genetic relationships dendrogram among populations was established using the UPGMA method, which was based on SRAP data, where 12 populations were divided into three classes on $\mathrm{D}=0.20$. One class was composed of nine populations of YN, GZ, SC, SX, JX, HN, HB, GX, GD; the second class comprised the $\mathrm{ZJ}$ and JX populations; the third class was the FJ population (Figure 1).

\section{Correlation between the genetic diversity and environmental factors of $\boldsymbol{H}$. cordata Thunb populations}

H. cordata Thunb. exhibits spatial scalability. Compared with other plants, it has a stronger adaptability and competitiveness. To further understand the ecological adaptation of $H$. cordata Thunb, we analyzed the correlation of genetic diversity and structure with environmental factors. The results showed that $\mathrm{NC}$ had an extremely significant negative correlation with soil organic matter $(\mathrm{P}=0.01, \mathrm{r}=-0.632)$ and $\mathrm{N}$ content $(\mathrm{P}=0.01, \mathrm{r}=-0.563)$, while $\mathrm{PD}$ and $\mathrm{D}$ had an extremely significant positive correlation with soil organic matter $(\mathrm{P}=$ $0.01, \mathrm{r}=0.635$ and $\mathrm{P}=0.05, \mathrm{r}=0.469$, respectively $)$ and $\mathrm{N}$ content $(\mathrm{P}=0.01, \mathrm{r}=0.561$ and $\mathrm{P}=$ 
$0.05, \mathrm{r}=0.429$, respectively), respectively. By contrast, $\mathrm{NC}, \mathrm{PD}$, and D were not significantly correlated with other habitation factors. PPB had a significant positive correlation with soil organic and $\mathrm{N}$ content, and an extremely significant positive correlation with soil $\mathrm{Cu}$ content, but not with other environmental factors. The value for $h \mathrm{had}$ a significant positive correlation with soil $\mathrm{Cu}$ content, but not for other environmental factors. The value of I had an extremely significant positive correlation with altitude and soil $\mathrm{P}$ content, but an extremely significant negative correlation with $\mathrm{K}, \mathrm{Fe}, \mathrm{Mn}$, and $\mathrm{Zn}$ contents. $G_{\mathrm{ST}}$ had a significant positive correlation with latitude, $\mathrm{N}$, and $\mathrm{Zn}$ and an extremely significant positive correlation with $\mathrm{K}, \mathrm{Fe}$, and $\mathrm{Cu}$. $N_{\mathrm{m}}$ had a significant positive correlation with latitude, $\mathrm{N}, \mathrm{K}$, and $\mathrm{Zn}$ contents, and an extremely significant positive correlation with $\mathrm{Fe}$ and $\mathrm{Cu}$ contents. In addition, all genetic parameters were not significantly correlated with soil pH and longitude (Table 8).

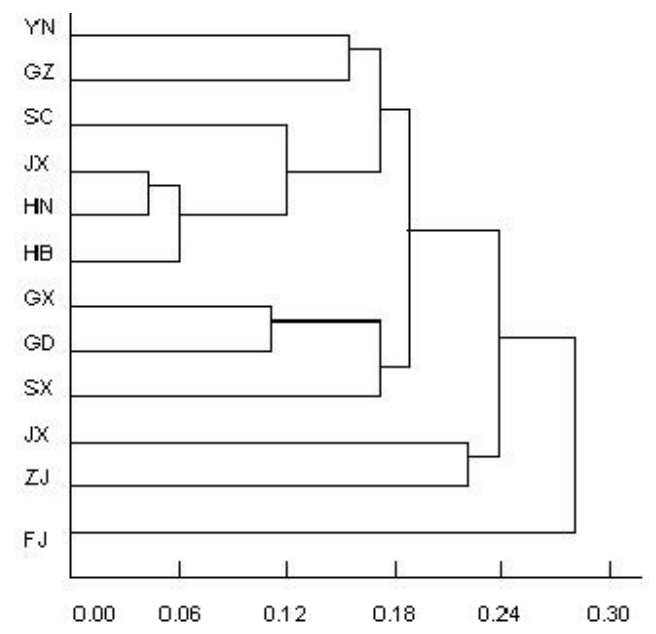

Figure 1. Dendrogram of UPGMA method cluster analysis based on Nei's genetic distance of SRAP data generated by the 41 primer combinations.

Table 8. The correlation between genetic diversity and habitation factors of Houttuynia cordata Thunb populations.

\begin{tabular}{l|c|c|c|c|c|c|c|c|c|c|c|c}
\hline & $\mathrm{pH}$ & Altitude $(\mathrm{m})$ & Latitude & Longitude & $\begin{array}{c}\text { Organic } \\
(\mathrm{g} / \mathrm{kg})\end{array}$ & $\begin{array}{c}\mathrm{N} \\
(\mathrm{g} / \mathrm{kg})\end{array}$ & $\begin{array}{c}\mathrm{P} \\
(\mathrm{mg} / \mathrm{kg})\end{array}$ & $\begin{array}{c}\mathrm{K} \\
(\mathrm{mg} / \mathrm{kg})\end{array}$ & $\begin{array}{c}\mathrm{Fe} \\
(\mathrm{mg} / \mathrm{kg})\end{array}$ & $\begin{array}{c}\mathrm{Mn} \\
(\mathrm{mg} / \mathrm{kg})\end{array}$ & $\begin{array}{c}\mathrm{Cu} \\
(\mathrm{mg} / \mathrm{kg})\end{array}$ & $\begin{array}{c}\mathrm{Zn} \\
(\mathrm{mg} / \mathrm{kg})\end{array}$ \\
\hline $\mathrm{NC}$ & -0.125 & -0.010 & 0.235 & -0.108 & $-0.632^{* *}$ & $-0.563^{* *}$ & 0.269 & -0.054 & 0.045 & -0.076 & 0.251 & 0.057 \\
\hline $\mathrm{PD}$ & 0.129 & 0.054 & -0.218 & 0.115 & $0.635^{* *}$ & $0.561^{* *}$ & -0.271 & 0.046 & -0.064 & 0.067 & -0.259 & -0.059 \\
\hline $\mathrm{D}$ & -0.226 & 0.301 & -0.053 & -0.049 & $0.469^{*}$ & $0.429^{*}$ & 0.303 & -0.246 & -0.280 & -0.142 & -0.162 & -0.274 \\
\hline $\mathrm{PPB}$ & -0.269 & 0.169 & -0.169 & -0.151 & $0.466^{*}$ & $0.425^{*}$ & -0.075 & 0.269 & 0.054 & -0.039 & $0.612^{* *}$ & 0.251 \\
\hline $\mathrm{h}$ & -0.254 & 0.069 & -0.211 & -0.007 & 0.226 & -0.233 & -0.234 & 0.207 & 0.352 & -0.059 & $0.438^{*}$ & 0.179 \\
\hline $\mathrm{I}$ & -0.238 & $0.606^{* *}$ & -0.237 & -0.178 & -0.145 & -0.234 & $0.617^{* *}$ & $-0.680^{* *}$ & $-0.638^{* *}$ & $-0.626^{* *}$ & -0.224 & $-0.655^{* *}$ \\
\hline $\mathrm{GST}$ & -0.312 & -0.013 & $0.519^{*}$ & 0.226 & 0.377 & $0.475^{*}$ & -0.271 & $0.515^{*}$ & $0.705^{* *}$ & 0.316 & $0.589^{* *}$ & $0.479^{*}$ \\
\hline $\mathrm{Nm}$ & 0.285 & -0.028 & $-0.474^{*}$ & 0.282 & -0.376 & $-0.456^{*}$ & 0.243 & $-0.505^{*}$ & $-0.625^{* *}$ & -0.286 & $-0.639^{* *}$ & $-0.443^{*}$ \\
\hline
\end{tabular}

$* \mathrm{P}<0.05 ; * * \mathrm{P}<0.01$.

\section{DISCUSSION}

\section{Genetic diversity and structure of $H$. cordata Thunb populations}

The Simpson diversity index (D) reflects the relative frequency of a special genotype 
of a certain population. A high $\mathrm{D}$ value means that nearly every plant of the sampling population has a different heredity, $\mathrm{D}$ values equal to 1 indicate that each plant has a unique multi-locus genotype, a low D value means that certain genotypes are sampled repeatedly within populations, and $\mathrm{D}$ values equal to 0 indicate that all plants have a common multi-locus genotype (Waycott et al., 1997). Many studies have shown that the average ratio of different genotypes (PD) and Simpson diversity index (D) of asexually reproduced plants are 0.62 (0.1-1.00) and 0.75 (0.13-1.00), respectively (Widén et al., 1994). Our results showed that the average values of PD and D were 0.91 and 0.97 , respectively. Although these values are higher than those mentioned in the literature, they are within the range of previously reported values.

Earlier studies have considered that the genetic diversity of the asexually reproducing plants was lower than that of the sexually reproducing plants (Hamrick and Golt, 1990), but more and more research has found that the genetic diversity of the asexually reproducing plants is not low (Eckert and Barrett, 1993), and sometimes can be very high. For example, the genetic diversity was as high as 0.983 for Leymus chinensis ( $\mathrm{Zu}$ and Cui, 2002), 0.988 for the Cyclobalanopsis glauca population (Chen and Song, 1997), and 0.992 was measured using the ISSR molecular marker technique for Potamogeton malaianus population (Chen et al., 2006). These phenomena could be attributed to the existing population and was established with plants of different origins and populations (Pappert, 2002).

Our study showed that the $N_{\mathrm{m}}$ among $H$. cordata Thunb. populations was lower than 1 , and the $G_{\mathrm{ST}}$ was higher than 0.51 (reaching a $1 \%$ significance level), indicating that the gene exchange among populations was fewer and genotypes were strongly, regionally distributed. These features were possibly due to the nature of asexual reproduction, and the important function of sexual reproduction, in the life history of $H$. cordata Thunb. Moreover, the existence of many genotypes among populations may contribute to regional ecological adaptation and subsequently lead to differentiation among populations. The number of plants per clone was 1.58 on average, but varied significantly among different clones, indicating that different clones may have different growth and adaptation abilities, and therefore different competitiveness.

\section{Correlation between the genetic diversity and habitation factors}

The effects of environmental factors on genetic diversity are debatable among scholars. Some believe that adversities such as disease, pests, cold, drought, and others are limiting factors on plants growth. After long-term exposure to the adverse conditions, plants growing in this environment develop adaptive mechanisms, such as genetic resistance, thereby increasing the genetic sub-differentiation and diversity within populations (Ricardo and O'Connell, 2005). In contrast, some scholars believe that environmental factors are not correlated with genetic diversity (Dorken and Husband, 1999; Ruggiero et al., 2005a). Our results showed that the genetic variation of different $H$. cordata Thunb. populations is significantly $(\mathrm{P}<0.05)$ orrelated at different levels with environmental factors, except soil $\mathrm{pH}$ and longitude, indicating that $H$. cordata Thunb. populations exhibit heteroplasmy. Moreover, there are few gene flows $(0.47)$ among $H$. cordata Thunb. populations, which influence the spatial pattern of their genetic diversity and their mating patterns.

\section{Causes of differentiation among $\boldsymbol{H}$. cordata Thunb populations}

The breeding system is an important factor affecting genetic diversity and structure.

Genetics and Molecular Research 15 (3): gmr.15038780 
Generally, distant mating and terminally successional species have a higher genetic diversity. The genetic diversity of self-mating and mixed-mating species is lower than that of outbreeding species (Parker and Hamrick, 1992; McClintock and Waterway, 1993; Li and Ge, 2001; Hayashi et al., 2001; Ferriol et al., 2003). The difference in the genetic diversity of $H$. cordata Thunb. populations is related to their life history, especially the renewal and addition to the population, which includes sexual reproduction and sexual reproduction patterns (Hamrick and Godt, 1996). The function of sexual reproduction lies in creating new gene combinations and accumulating a large number of mutations, thus accelerating environmental adaption and new species formation (Aspinwall and Christian, 1992). When seedling renewal becomes difficult, asexual reproduction is thought to ensure the stabilization of partial populations (Ruggiero et al., 2005b). If there were no mutations, migration, selection, or seedling renewal through sexual reproduction, genetic diversity would disappear over time until only one genotype exists within the population. However, if there were few seedlings renewed in a short time, the genetic diversity could be maintained or raised (Watkinson and Powell, 1993). In this study, the average number of plants per clone among $H$. cordata Thunb. populations was 1.58 . Moreover, the ratio of different genotypes was higher, suggesting that in the early stages of population establishment, $H$. cordata Thunb populations consisted of many plants with different genotypes, rather than being formed by fragmentation or the spread of existing clones through asexual reproduction; that is, $H$. cordata Thunb populations can have multiple origins, which creates rich genetic diversities.

Genetic obstacles, establisher effects, and gene flow have important functions that affect the genetic diversity of asexually reproducing plants. In addition, statistics and the phenological conditions of different regions also affect the level of genetic diversity (Li et al., 1996; Schnabel and Hamrick, 1997; Persson and Gustavsson, 2001; Hangelbroek et al., 2002). It is possible that only a few plants established the population at an early stage, which, together with plants of different genotypes, affected the genetic structure to a large extent. Therefore, the genetic diversity and structure of $H$. cordata Thunb. populations were the systematic result of many factors closely correlated to spread, spread pattern, and sexual reproduction.

\section{ACKNOWLEDGMENTS}

The authors are grateful to the key research and development program of the Hunan province (agricultural support field) (\#2015NK3016) for providing funding.

\section{REFERENCES}

Albert T, Raspe O and Jacquemart A (2003). Clonal structure in Vaccinium myrtilus L. Revealed by AFLP and RAPD markers. Int. J. Plant Sci. 164: 649-655. http://dx.doi.org/10.1086/375373

Aspinwall N and Christian T (1992). Clonal structure, genotypic diversity and seed production in populations of Filipendula rubra (Rosaceae) from the north-central United States. Am. J. Bot. 79: 294-299. http://dx.doi.org/10.2307/2445018

Budak H, Shearman RC, Parmaksiz I, Gaussoin RE, et al. (2004). Molecular characterization of Buffalograss germplasm using sequence-related amplified polymorphism markers. Theor. Appl. Genet. 108: 328-334. http://dx.doi. org/10.1007/s00122-003-1428-4

Budak H, Shearman RC, Parmaksiz I and Dweikat I (2004). Comparative analysis of seeded and vegetative biotype buffalograsses based on phylogenetic relationship using ISSRs, SSRs, RAPDs, and SRAPs. Theor. Appl. Genet. 109: 280-288. http://dx.doi.org/10.1007/s00122-004-1630-z

Chen XY and Song YC (1997). Clonal diversity in cyclobalanopsisglauca populations and its relationship with environmental factors. Acta Phytoecol. Sin. 21: 342-348.

Genetics and Molecular Research 15 (3): gmr.15038780 
Chen Y, Li Q, Wu W and Li W (2006). [Genetic diversity and clonal structure of Potamogeton malaianus populations]. Ying Yong Sheng Tai Xue Bao 17: 2034-2040.

Dorken ME and Husband BC (1999). Self-sterility in the understory herb Clintonia borealis (Liliaceae). Int. J. Plant Sci. 160: 577-584. http://dx.doi.org/10.1086/314141

Eckert CG and Barrett SCH (1993). Patterns of genotypic diversity and clonal reproduction in Decodon verticillatus (Lythraceae). Am. J. Bot. 80: 1175-1182. http://dx.doi.org/10.2307/2445546

Esselman EJ, Li JQ and Crawford D (1999). Clonal diversity in the rare Calamagrostisporteri ssp. insperata (Poaceae): comparative results for allozymes and random amplified polymorphic DNA (RAPD) and within-simple sequence repeat (ISSR) markers. Mol. Ecol. 8: 443-451. http://dx.doi.org/10.1046/j.1365-294X.1999.00585.x

Ferriol M, Picó B and Nuez F (2003). Genetic diversity of a germplasm collection of Cucurbita pepo using SRAP and AFLP markers. Theor. Appl. Genet. 107: 271-282. http://dx.doi.org/10.1007/s00122-003-1242-z

Hamrick JL and Golt MJW (1990). Allozyme diversity in plant species. In: Plant population genetics, breeding and genetic resources (Brown AHD, Clegg MJ and Kahler AL, eds.). Sinauer, Sunderland, 43-63.

Hamrick JL and Godt MJW (1996). Effects of life history traits on genetic diversity in plant species. Philos. Trans. R. Soc. Lond. B Biol. Sci. 351: 1291-1298. http://dx.doi.org/10.1098/rstb.1996.0112

Hangelbroek HH, Ouborg NJ, Santamaría L and Schwenk K (2002). Clonal diversity and structure within a population of the pondweed Potamogeton pectinatus foraged by Bewick's swans. Mol. Ecol. 11: 2137-2150. http://dx.doi. org/10.1046/j.1365-294X.2002.01598.x

Hayashi K, Yoshida S and Frederick HU (2001). Molecular systematics in the genus Clintonia and related taxa based on rbcL and matK gene sequence data. Plant Species Biol. 16: 119-137. http://dx.doi.org/10.1046/j.1442-1984.2001.00057.x

Li A and Ge S (2001). Genetic diversity and clonal diversity of Psammochloa villosa (Poaceae) detected by ISSR markers. Ann. Bot. (Lond.) 87: 585-590. http://dx.doi.org/10.1006/anbo.2001.1390

Li SF, Chang ZY and Yuan YM (1996). The origin and dispersal of the genus ClintoniaRaf. (Liliaceae): evidence from its cytogeography and morphology. Caryologia 49: 125-135. http://dx.doi.org/10.1080/00087114.1996.10797357

Lin Z, He D and Zhang X (2005). Linkage map construction and mapping QTL for cotton fibre quality using SRAP, SSR and RAPD. Plant Breed. 124: 180-187. http://dx.doi.org/10.1111/j.1439-0523.2004.01039.x

McClintock KA and Waterway MJ (1993). Patterns of allozyme diversity and clonal diversity in Carex lasiocarpa and $C$. pellita (Cyperaceae). Am. J. Bot. 80: 1251-1263. http://dx.doi.org/10.2307/2445708

O'Hanlon P, Briese DT and Peakall R (2000). A review of new PCR-based genetic markers and their utility to weed ecology. Weed Res. 40: 239-254. http://dx.doi.org/10.1046/j.1365-3180.2000.00191.x

Okazakik K, Sakamoto K and Kuchir K (2007). Mapping and characterization of FLC homologs and QTL analysis of flowering time in Brassica oleracea. Theor. Appl. Genet. 114: 595-608.

Pappert W (2002). The Evolutionary Process: A Critical Study of Evolutionary Theory. New York, Columbia University Press 2nd ed.

Parker KC and Hamrick JL (1992). Genetic diversity and clonal structure in a columnar cactus, Lophocereus schottii. Am. J. Bot. 79: 86-96. http://dx.doi.org/10.2307/2445201

Persson HA and Gustavsson BA (2001). The extent of clonality and genetic diversity in lingonberry (Vaccinium vitisidaea L.) revealed by RAPDs and leaf-shape analysis. Mol. Ecol. 10: 1385-1397. http://dx.doi.org/10.1046/j.1365294X.2001.01280.X

Pleasants JM and Wendel JF (1989). Genetic diversity in a clonal narrow endemic, Erythronium propullens, and its progenitor, E. albidum. Am. J. Bot. 76: 1136-1151. http://dx.doi.org/10.2307/2444826

Ricardo TC and O'Connell MA (2005). Genetic diversity of drought-responsive genes in populations of the desert forage Dactylis glomerata. Plant Sci. 108: 1327-1335.

Ruggiero MV, Reusch TBH and Procaccini G (2005a). Local genetic structure in a clonal dioecious angiosperm. Mol. Ecol. 14: 957-967.http://dx.doi.org/10.1111/j.1365-294X.2005.02477.x

Ruggiero MV, Capone S and Pirozzi P (2005b). Mating system and clonal architecture: a comparative study in two marine angiosperms. Evol. Ecol. 19: 487-499. http://dx.doi.org/10.1007/s10682-005-0292-x

Schnabel A and Hamrick JL (1997). Organization of genetic diversity within and among populations of Gleditsia triacanthos (Leguminosae). Am. J. Bot. 7: 1060-1069.

Watkinson AR and Powell JC (1993). Seeding recruitment and the maintenance of clonal diversity in plant populationsa computer simulation of Ranunculus repens. J. Ecol. 81: 707-717. http://dx.doi.org/10.2307/2261668

Waycott M (1995). Assessment of genetic diversity and clonality in the seagrass Posidoniaaustralis using RAPD and allozyme analysis. Mar. Ecol. Prog. Ser. 16: 289-295. http://dx.doi.org/10.3354/meps116289

Waycott M, James SH and Walker D (1997). Genetic diversity within and between populations of posidoneaaustralis, a hydrophilous, clonalseagrass. Heredity 79: 408-417. http://dx.doi.org/10.1038/hdy.1997.175

Genetics and Molecular Research 15 (3): gmr.15038780 
Widén B, Cronenberg N and Widén M (1994). Genotypic diversity, molecular markers and spatial distribution of genets in clonal plant, a lite-raure survey. Folia Geobot. Phytotaxon. 29: 245-263. http://dx.doi.org/10.1007/BF02803799

$\mathrm{Wu} \mathrm{W}$, Zheng YL, Chen L, Yang RW, et al. (2002a). Isozymes diversitys among the germplasm resources of HouttuyniaThunb in Sichuan. J. Chin. Med. Mater. 25: 695-698.

Wu W, Zheng YL, Chen L, Wei YM, et al. (2002b). RAPD analysis on the germplasm resources of herbaHouttyniae. Acta Pharmacol. Sin. 37: 986-992.

Wu W, Zheng YL, Yang RW, Chen L, et al. (2003). The diversitys of chromosome number and cytomixis in the germplasm resources of Houttuynia cordata Thunb. Acta Phytotaxonomica Sin. 41: 245-257.

Yeh FC, Yang RC and Boyle T (1997). Popgene, the user friendly shareware for population genetic analysis. Edmonton: University of Alberta, Molecular Biology and BiotechnologyCenter.

Zhong J, Wang K and Qiu P (2009). Genetic diversity of populations in germplasm resources of houttuyniacordata Thunb. Acta Agric. Boreali-Sin. 24: 94-100.

Zhong J, Wang K and Qiu P (2010). An analysis of genetic diversity of Houttuynia cordata Thunb. population by SRAP molecular markers. Plant Physiol. Comm. 46: 210-216.

Zu YG and Cui JZ (2002). Clonal diversity in Leymus chinensis populations. Acta Phytoecol. Sin. 26: 157-162.

Genetics and Molecular Research 15 (3): gmr.15038780 